\title{
Learning Management of Bahasa in Senior High Schools
}

\author{
Juni Ahyar
}

Department of Management, Universitas Malikussaleh, North Aceh, Indonesia

Rasyimah

Department of Secretary, Universitas Malikussaleh, North Aceh, Indonesia

\begin{abstract}
Purpose - This study aims to describe the planning of learning, learning organizing implementation, and evaluating the learning of Bahasa in a high school in Lhokseumawe.

Methodology - The research method was descriptive analysis with a qualitative approach. Data collection used the techniques of observation, interview, and literature review. The subjects of research were the principal, vice principal, Chairman of Department, and Bahasa teachers in the high school. The data obtained were analyzed with the technique of reduction, display, and verification.

Findings - The results showed that the lessons plan in the high school have been compiled by the Indonesian language/Bahasa teachers, including analyzing subjects, drawing up the annual and semester programs, and syllabus. All the planning of learning Bahasa have been well structured and documented. The implementation of the orientation direction or Bahasa Learning is adapted to the needs and level of education. The implementation of study conducted showed the positive things in accordance with the school-based curriculum.

Research Limitations/Implications - Organizing learning Bahasa also showed the positive things based on the management system. Bahasa teachers carried out their roles and their responsibilities based on their job description. This condition has brought positive influence on the quality of learning Bahasa which shows an increase from year to year.

Practical Implications - Activities and aspects of the Bahasa learning adapted to the assessment are based on the syllabus and compiled lesson plan. The evaluation phase is applied to improve the learning activities. This form of evaluation was done either by oral or writing.

Originality/Value - This is the first research to identify learning management of Bahasa in senior high schools in Lhokseumawe.
\end{abstract}

Keywords Learning, management, language

All papers within this proceedings volume have been peer reviewed by the scientific committee of the Malikussaleh International Conference on Multidisciplinary Studies (MICoMS 2017).

\section{Introduction}

Education is viewed as an effort to develop the intellectual life of the nation, develop Indonesian people who have faith and piety, are ethically sublime, and also have knowledge and skills. Through the education process, they will be able to express themselves more

(C) Juni Ahyar, Rasyimah. Published in the Emerald Reach Proceedings Series. Published by Emerald Publishing Limited. This article is published under the Creative Commons Attribution (CC BY 4.0) licence. Anyone may reproduce, distribute, translate and create derivative works of this article (for both commercial and non-commercial purposes), subject to full attribution to the original publication and authors. The full terms of this licence may be seen at http://creativecommons.org/licences/by/4.0/ legalcode

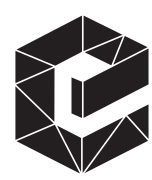

Emerald Reach Proceedings Series Vol. 1 Emerald Publishing Limited 2516-2853 DOI 10.1108/978-1-78756-793-1-00009 
Proceedings of MICoMS 2017 with tact. The implementation of the education system in Indonesia is a comprehensive education oriented approach. In a comprehensive perspective, as Murniati (2008, p. 11) states that "the practice of national education of Indonesia seeks to implement are integrative and comprehensive conception of education that nuanced nationality, religious, humanitarian, and simultaneous creation." On the basis of this, the efforts to embody the good quality of education shall consider various sides related to education.

Based on the above quotations, it is obvious that effective teachers are those who are able to encourage students in learning. This process will be easily realized by the teacher, while learning he/she is able to carry out these activities optimally. Good learning management will be capable of bridging the gap between teachers as facilitators with learners as subjects in the study. "A democratic learning is a very useful alternative for teachers in assisting the development of learners, particularly on the social aspect of learners "(Umiarso, 2010, p. 256). Without the mastery of learning management, learning achievements of students or the quality of education will hardly be realized to be better.

The methods teachers used should be in accordance with the curriculum and supported by the sources and media that exist at the school. As well as in Bahasa learning, teachers should ideally use a method in accordance with learning Bahasa method, such as group work, giving assignments, and other cooperative learning models. The use of variation methods is part of the effort of learning Bahasa management in addition to grant the motivation to students and the implementation of the evaluation. This reality as it took place at high school, Bahasa teachers had already implemented learning management. However, lack of interest and motivation to learn Bahasa became a major obstacle in the streamline learning. In addition, the majority of high school students were male students which also became a problem for Bahasa teachers in classroom management.

Other issues that the recruitment of high school students are not based on district as well as applicable to public schools. There were two departments in high school, namely Department of Science and Department of Social who receive the same amount of learning hours for Bahasa subject, which was four-hour lesson per week. When it was viewed from the curriculum, with the portion of just four hours lessons per week was not sufficient. Ideally Bahasa lessons should be given six hours or more in a week, as most subjects on all majors in high school are associated with Bahasa. Due to the lack of hours of Bahasa lessons, it became an obligation for Bahasa teachers to master learning management that is capable of applying learning effectively and efficiently.

\section{Research methods}

This research used descriptive qualitative approach method. Data collection techniques used were observation, interviews, and documentation study. The subjects of research were the principal, vice principal, head of department, and teachers of Bahasa at high school. Techniques of data analysis in this study were included steps of data reduction, display data, and acquire conclusion.

\section{Review of the literature}

Management is an aspect used to examine human efforts which enable combining to cooperate in the efforts to achieve a better life. Management is often defined as the knowledge, tips, and profession (Usman, 2007). It is said a science by Luther Gullick because management is seen as a field of knowledge that is systematically trying to understand why and how people collaborate. As tips given by Follett, management achieve goals through how to set up others in carrying out the task. It is viewed as a profession because it is based 
on management by expertise to achieve a feat of managers, and professionals required by a code of ethics.

Learning is a process of interaction between the participants of the study with the teacher or the learning resource in a learning environment for the achievement of the learning objectives (Uno, 2009). Learning is a teacher technique in order to make function and interaction between students with all learning components in a learning activity more effective and efficient to achieve the objectives of teaching.

School management should also understand the development of modern industrial management, so that it is capable of designing, implementing, controlling, and improving the performance of the education system that meets their needs (Umiarso, 2010, p. 116). School management process includes four stages, namely, planning, organizing, deployment, and monitoring, in accordance with the management functions.

Directorate General Education and Secondary or mostly called Direktorat Jenderal Pendidikan dan Menengah (2006, p. 67) elaborated the implementation process management curriculum which are conducted in four phases as follows: (a) planning, (b) organizing and coordination, (c) implementation, and (d) control (supervision).

The process of drafting the plan at the school includes seven stages, namely: (a) reviewing the relevant policy, (b) analyzing the condition of the schools, (c) formulating objectives, (d) collecting related data and information, (e) analyzing data information, (f) formulating alternatives and selecting an alternative program, and (g) establishing measures of activity implementation. The preparation of an excellent plan will give positive results against all activities conducted. Cahyani (2005) states "It is important to planning strategy because it can be used to identify something (and other personnel) that could hinder the implementation of the strategy."

At the stage of organizing, the principal regulates the division of teaching duties, drafting time table and schedule of extracurricular activities. Depdikbud (2006, p. 67) sets five stages, which include: "the division of teachers' duties, the arrangement of time table, the preparation of remedial activities, preparation of a schedule of extracurricular activities, and preparation of schedules of teaching support for teachers."

At the stage of implementation, the teachers will do their job according to what has been provided in the learning schedule, extracurricular schedule, and teaching support. In this stage the principal carried out supervision with the aim to help teachers who have difficulty in carrying out their work.

There are two aspects that should get attention namely (1) the type of evaluation to be used and (2) the utilization of evaluation results.

Student management is the overall process of cooperation in the field of studentship. The areas of cooperation in the management of students in resolving the issues are related to students. The problems here are in the form of conducting the census, organizing new students admission activities, fostering discipline of students, holding a special service programs for students, etc.

"The management of the students (learners) is the whole process of the activities planned and organized deliberately and continuously coaching to all learners (in the respective institutions) in order to follow the teaching-learning process effectively and efficiently, in order to achieve the educational goals that have been set" (Gunawan, 2007, p. 9). The purpose of the student management is to organize the completion of the tasks relating to the students at the institution concerned. By having the settings, it is expected that all tasks relating to students progress effectively and efficiently, so as to facilitate achievement of the purposes of the institution. 
Proceedings of MICoMS 2017
Learning strategies can be defined as any activity chosen that provides facilities or assistance to learners toward a specific learning goal. Good learning strategies come into application of learning management and determine the success at school. "The learning strategy is the means chosen to deliver the learning methods in the learning environment. Further he elaborated that learning strategies mentioned include the nature of the scope and sequence of learning activities that can provide the learning experience of learners" (Uno, 2009, p. 1).

Bahasa as one of the basic sciences developed very rapidly. Bahasa is considered as a branch of science that is urgently needed, because in everyday life many things we come across related to Bahasa. "The role of Bahasa in the world today is very dominant, since $60-80 \%$ progress achieved developed nations depend largely on the Bahasa" (Hudoyo, 2005 , p. 2). Bahasa or Indonesian language is one of the fields of study are taught to students at all levels of formal education has its own learning objectives called language learning goals. In its implementation so that the goal can be reached, it should be spelled out again into more specific objectives that are now known as basic competence.

\section{Results and discussion}

Learning Bahasa planning at high school begins with several activities, including the preparation of a Plan of Study Program. Planning of learning contained in the implementation of curriculum management as contained in the Document I school-based curriculum.

The process of implementing the learning program that has already been in the syllabus, teachers of Bahasa at high school devised a plan of implementation of the learning. It is the handbook for Bahasa teachers in implementing the learning in the classroom, library, and/or the basic competencies for each field. What is contained here are things that directly relate to the activities of Bahasa learning in an attempt to attain the mastery of basic competencies.

Every process of preparing Bahasa teachers' syllabus and lesson plan lists the standards of competence based on basic competencies which are organized in the lesson plans. The contents of the syllabus and lesson plan in detail contains learning objectives, learning materials, learning methods, the steps of learning activities, learning resources, and assessment. "The teachers need to be encouraged to continue refining the learning strategies, for example, by implementing the follow-up review in learning (class room action research)" (Umaedi, 2006, p. 7). The implementation of the curriculum in school includes four stages, namely: (1) planning, (2) organizing and coordination, (3) implementation, and (4) control (The Depdiknas, 2005, p. 68).

The planning of any activity will determine what will be done in the learning process. "Planning with regard to the determination of what should be done. Planning precedes implementation, given the planning is a process to determine where to go and identify the necessary requirements in the most effective and efficient” (Harjanto, 2011, p. 2). The results showed that the principal and Bahasa teachers of high school are already implementing the planning process of learning very well. This gives a positive influence towards quality improvement of learning Bahasa. A planning objective will be achieved optimally when it is grounded on seven are (1) planning based on clear goals; (2) the existence of unity of plan; (3) logical (reasonable); (4) contain elements of continuity; (5) simple and clear; (6) flexible; and (7) stability (Harun, 2007, p. 2).

A learning approach is done with a program based on activities that have been arranged, so that the entire conditioning and basic capabilities of students can be developed carefully. In carrying out the activities of learning Bahasa, most Bahasa teacher in high school apply modern learning methods. This means in the implementation of learning, teachers are not 
only focused on the application of conventional methods, such as lecturing, questioning and answering, and awarding the task, but also have started to implement modern learning methods or models like the instructional model of cooperative. However, a cooperative learning method has not been applied continuously.

Efforts to realize the implementation of good learning must be supported by different components, such as facilities and teachers. Personnel management are part of school management who pay attention to the people in the organization of the school. Personnel management activities include recruitment, placement, and training to develop and improve their well-being. Workforce personnel who are in school include: "educational members are permanent and temporary teachers as well as administrative staffs" (Gunawan, 2006, p. 14).

An important factor in organization according to the explanation of the informant (the principal of high school) is a synergistic relationship between fellow teachers, institutions with community/parents of students, as well as the presence of an intensive communication with the tangle of related parties/Government. Organizing the learning will not be carried out properly if a conducive working relationship/good relationship among the parties mentioned above does not exist.

Through organizing a good learning of Bahasa, efficiency in high school is achieved. "The efficiency of education means to have the link between utilization of limited educational resources so as to achieve a high optimization. In education costs, efficiency will only be determined by accuracy in utilizing education budget by giving priority on education input factors that can spur achievement of learning" (Fattah, 2006, p. 35).

Evaluation or assessment is a set of activities that are carried out systematically, which includes the determination of the purpose, design and development of instruments, data collection, analysis, and interpretation to specify a value with the specified assessment standards. The purpose of evaluation or appraisal is done to answer whether there are significant differences between the results desired or planned with the reality in the field.

Assessment of learning in high school variety is "targeted provide input to program planning, give input to a continuation, extension and termination of the learning programme has been implemented, give input to modify the learning programs, as well as for the follow-up to the programme which has not been properly realised" (Sudjana, 2006, p. 36-37). "Evaluation for school age children can be given to parents in the form of a report at the end of the semester. The goal is parents know how the development of their children, whether their children had reached the target developments or otherwise" (Hariwijaya and Sukaca, 2009, p. 122).

\section{Implication}

It is expected that the school principal, Deputy Head of the curriculum, and the Chairman of the Department will pay attention to the factor of planning in learning Bahasa at high school. This effort should involve all Bahasa teacher in formulating learning planning. In addition, we must consider a planning study based on the national curriculum of the Ministry of education. The principal and teaching staff of Bahasa at high school should make a concerted effort to improve the implementation of Indonesian language learning. This effort is reviving subject teachers activities. In addition, it also needs support from the Government about the importance of procurement or upgrading training for Bahasa teachers so that the professionalism and competence will increase. The head office of education department should improve the coordination of the institution of the schools for the sake of increasing the quality of education. This effort is increasing the intensity of the visit to the school (senior high school) as well as seeking completeness of Bahasa learning facilities and infrastructure. It is recommended to the community and parents of high school children that participating actively and providing constructive input towards 
Proceedings of evaluation and development of high school, will help the school become more advanced in MICoMS 2017 the future.

\section{Conclusion}

Planning of the learning of Bahasa at high school has been compiled by Bahasa teachers, including analyzing Bahasa subjects, drawing up the annual programme, compiling semester and annual program, syllabus, and preparing the plan of the learning program. All the planning of learning Bahasa is well structured and documented. Implementation of Bahasa learning at high school is implemented based on the unit level of school-based curriculum that had been prepared. Organizing learning Bahasa at high school is already based on a management system. Bahasa teachers carry out their roles and their responsibilities in accordance with their job description. This condition largely determines the quality of Bahasa learning in high school, which shows an increase from year to year. Constraints that are still found in the enhancement of learning among others are still teachers who manage the Bahasa classes that are not in line with the learning management. Activities and aspects of the assessment of the learning Indonesian language in high school are based on the arranged syllabus and the lesson plan. The evaluation phase is done to improve the learning activities. This form of evaluation is done either by oral or writing.

\section{References}

Ahyar, J. (2015). Bahasa Indonesia dan Penulisan Ilmiah, Biena Edukasi, Lhokseumawe.

Cahyani. (2005). Antisipasi Pengembangan Pendidikan dalam Rangka Otonomi Daerah, UPI, Bandung.

Depdiknas. (2005). Manajemen Peningkatan Mutu Berbasis Sekolah, Depdiknas, Jakarta.

Depdiknas. (2006). Pengembangan Sistem Pendidikan Tenaga Kependidikan Ke-21 SPTK-21, Depdiknas, Jakarta.

Dirjen Pendidikan Dasar dan Menengah. (2006). Pengelolaan Dana Pendidikan, Dirjen Pendidikan Dasar dan Menengah, Jakarta.

Gunawan, A. (2006). Administrasi Pendidikan, Rineka Cipta, Jakarta.

Harjanto. (2011). Perencanaan Pengajaran, Rineka Cipta, Jakarta.

Harun, C.Z. (2007). Fungsi-fungsi Dasar Manajemen dan Hubungan Ilmu Manajemen dengan Ilmuilmu Lain, Diktat Materi Kuliah-IV, Program Studi Magister Manajemen Pendidikan Unsyiah, Banda Aceh.

Murniati, A.R. (2008). Manajemen Stratejik Peran Kepala Sekolah dalam Pemberdayaan, Citapustaka Media Perintis, Bandung.

Sudjana, D. (2006). Evaluasi Program Pendidikan Luar Sekolah, untuk Pendidikan Nonformal dan Pengembangan Sumber Daya Manusia, Remaja Rosdakarya, Bandung.

Hariwijaya and Sukaca. (2009). Kurikulum dan Mutu Pendidikan Indonesia, Bumi Aksara, Jakarta.

Umiarso and Imam, G. (2010). Manajemen Mutu Sekolah di Era Otonomi Pendidikan, IRCiSoD, Jogyakarta.

Uno, H.B. (2009). Model Pembelajaran Menciptakan Proses Belajar Mengajar yang Kreatif dan Efektif, Bumi Aksara, Jakarta,

Usman, N. (2007). Manajemen Peningkatan Kinerja Guru, Mutiara Ilmu, Bandung.

\section{Corresponding author}

Juni Ahyar can be contacted at juniahyar@unimal.ac.id 